\title{
Biological and Oxidative Effect of Ellagic Acid on Saccharomyces cerevisiae: A New Way for Culture Developing
}

Ozlem Gok ${ }^{1}$

https://orcid.org/0000-0001-8521-6369

\section{Seda Beyaz ${ }^{1}$}

https://orcid.org/0000-0003-0436-8112

Abdullah Aslan ${ }^{2 *}$

https://orcid.org/0000-0002-6243-4221

${ }^{1}$ Firat University, Faculty of Science, Department of Biology, Elazig, Turkey; * ${ }^{2}$ Firat University, Faculty of Science, Department of Biology, Molecular Biology and Genetics Program, Elazig, Turkey

Editor-in-Chief: Alexandre Rasi Aoki

Associate Editor: Sinvaldo Baglie

Received: 2021.01.04; Accepted: 2021.04.28.

*Corresponding author: aaslan@firat.edu.tr, Tel: +90 424 2370000. (A.A.).

HIGHLIGHTS

- Ellagic acid (EA) reduces oxidative damage and thus it can protect $S$. cerevisiae against to ROS.

- SDS-PAGE results reveal that EA induces total protein synthesis.

- EA induces S. cerevisiae cell development and it reduces MDA levels and it increases GSH levels.

Abstract: In this study, the effects of Ellagic acid (EA) on protein expression in yeasts and cellular development were investigated. Four groups were formed. Groups: 1) Control group; yeast only cultivated group; 2) Ellagic Acid (EA) group: EA (10\%) given group; 3) Hydrogen peroxide $\left(\mathrm{H}_{2} \mathrm{O}_{2}\right)$ Group: The group given $\mathrm{H}_{2} \mathrm{O}_{2}$ (15 mM); 4) $\mathrm{EA}+\mathrm{H}_{2} \mathrm{O}_{2}$ group: $\mathrm{EA}(10 \%)+\mathrm{H}_{2} \mathrm{O}_{2}(15 \mathrm{mM})$ group. After sterilization, $\mathrm{EA}(10 \%)$ and $\mathrm{H}_{2} \mathrm{O}_{2}(15 \mathrm{mM})$ were added to the Saccharomyces cerevisiae (S. cerevisiae) cultures and the cultures were grown at $30{ }^{\circ} \mathrm{C}$ for 1 hour, 3 hours, 5 hours and 24 hours (overnight). S. cerevisiae cell growth, lipid peroxidation MDA (malondialdehyde) analysis and GSH (glutathione) level were analyzed by spectrophotometer. Total protein changes were determined by SDS-PAGE electrophoresis and measured by the Bradford method. According to the obtained results, compared with the $\mathrm{H}_{2} \mathrm{O}_{2}$ group, cell development (1, 3, 5 and 24 hours), GSH level and total protein synthesis (24 hours) were increased with EA, while MDA level (24 hours) decreased. These results show that EA reduces oxidative damage, increases cell growth and it has a protective effect to promote protein synthesis in $S$. cerevisiae culture.

Keywords: Ellagic acid; $\mathrm{H}_{2} \mathrm{O}_{2}$; Saccharomyces cerevisiae; SDS-PAGE. 


\section{GRAPHICAL ABSTRACT}

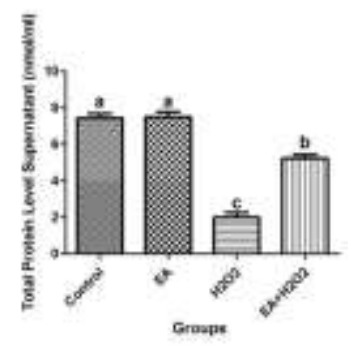

Ellagic Acid
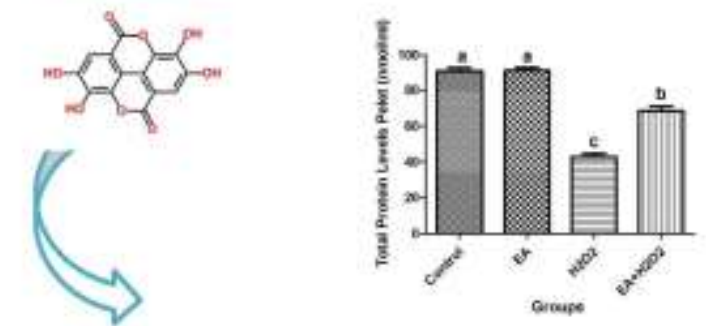

Saccharongces cerinisiae

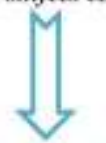

It has been deternined that ellagic acid promotes protein syuthesis in $S$ cervwsiace.

$\checkmark$ It is ohscrved that the protein density is increasod at a high, rate in the $\mathrm{EA}$ groxup onnpared to the $\mathrm{H}_{2} \mathrm{O}_{2}$ group.

- It was observed that MDI level was the highest in $\mathrm{H}_{2} \mathrm{O}$, group and decreansed riguificantly in $\mathrm{EA}$ group.

- I1 sis concluded that EA incrased the develogment of

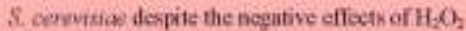
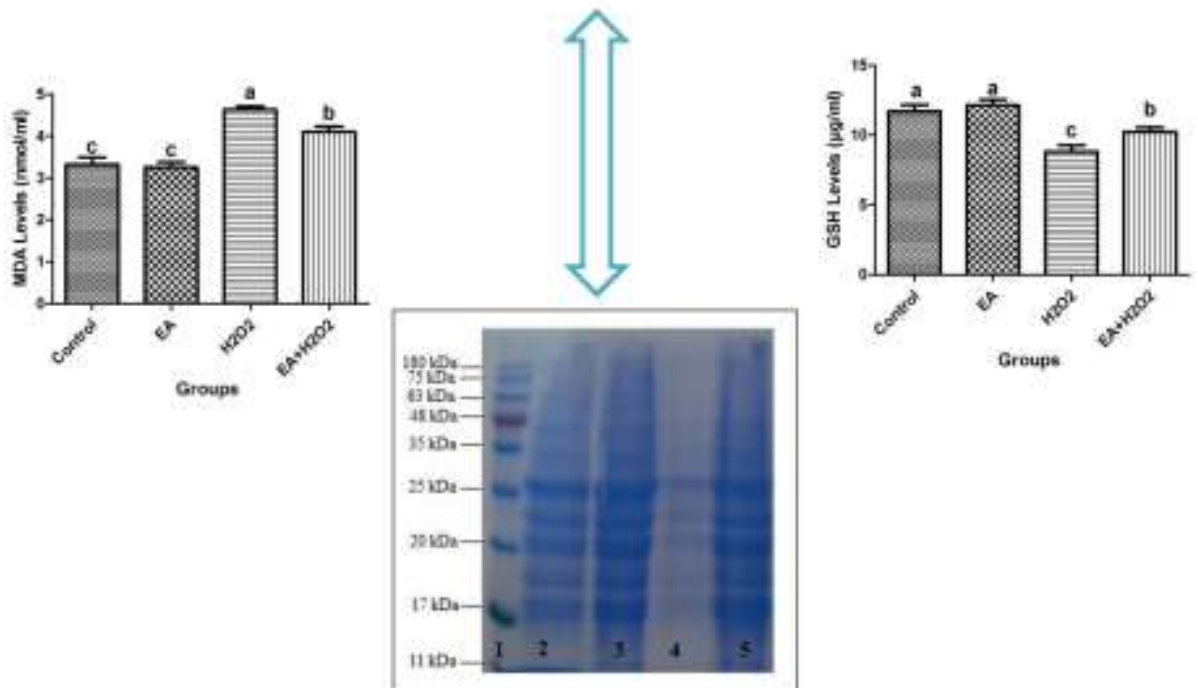

\section{INTRODUCTION}

The use of natural antioxidants instead of traditional treatments is thought to be an effective and safe alternative treatment $[1,2]$. Recently, herbal medicines have gained importance and popularity due to their reliability, effectiveness and low cost [3]. With the recent studies, it is stated that ellagic acid (EA) is one of the substances that have antioxidant, antimutagenic and anticarcinogenic properties naturally found in phenol structure in plants $[4,5]$. EA, 2,3,7,8-tetrahydroxy benzopyrene $(5,4,3 \mathrm{cde})$ is a member of benzopyran-5,10dione flavanoids. It is found in plants in the form of hydrolyzable tannins called ellagitannin. It contains four hydroxyl groups and two lactone groups known to protect cells from oxidative damage. Also, hydroxyl group is known to increase antioxidant activity in lipid peroxidation [6]. It is found in various plant species such as pomegranate, strawberry, grape, blackberry and raspberry. Due to its antioxidant and antiinflammatory properties, it has hepato, neuro and cardio protective properties $[7,8]$. It directly removes reactive oxygen species, hydroxyl radicals and hydrogen peroxide radicals. It also indirectly activates cellular antioxidant 
enzyme systems and prevents oxidative stress [9]. It has been reported to be effective in regression of various tumor types including lung cancer, colorectal carcinoma, esophageal cancer, hepatocellular carcinoma, tongue cancer, breast cancer, bladder cancer and prostate cancer [10]. It has been determined that EA provides defense against oxidative stress, improves insulin resistance and exerts antidiabetic activity thanks to its powerful antioxidant activity [11]. It was observed that EA decreased MDA levels, increased GSH, GPx, SOD and catalase activities and antioxidant status significantly improved [12].

$S$. cerevisiae is widely used as a cellular model to determine the antioxidant capacity of food and beverages. Because this model organism constitutes cellular response to oxidative stress and defense functions involved in this response [13,14]. Since their genetic structure and cellular properties are well known, its use continues to spread day by day and therefore it is one of the most preferred microorganisms in scientific studies. It is always used as model microorganisms in academical investigations. Recently, different fruit extracts which has rich in antioxidants, minerals and vitamins have been used on yeasts in many studies. Oxidative damage can be fully or partly abolished with assorted foods with powerful antioxidant efficacy. Numerous works revealed that various fruit ingredient raises cellular growing in yeasts, induces protein synthesis and monitored the preservative effect against to oxidative stress [15].

In this study the effects of EA on cellular growth and protein expression in $S$. cerevisiae were investigated. We believe that the results obtained from this study will contribute to the current literature.

\section{MATERIALS AND METHODS}

\section{Research Groups and Saccharomyces cerevisiae Development Conditions}

In this research, 4 groups were formed. Groups:

1. Control group; yeast only cultivated group;

2. Ellagic Acid (EA) group: EA (10\%) given group;

3. Hydrogen peroxide $\left(\mathrm{H}_{2} \mathrm{O}_{2}\right)$ Group: the group given $\mathrm{H}_{2} \mathrm{O}_{2}(15 \mathrm{mM})$;

4. $\mathrm{EA}+\mathrm{H}_{2} \mathrm{O}_{2}$ group: $\mathrm{EA}(10 \%)+\mathrm{H}_{2} \mathrm{O}_{2}(15 \mathrm{mM})$ group.

For growth and cultivation of yeasts, EA was added to YEPD (50 ml: $1.5 \mathrm{~g}$ yeast extract, $1.5 \mathrm{~g}$ tryptone, $1.5 \mathrm{~g}$ glucose) and improved for growth of $S$. cerevisiae $[16,17]$.

\section{Application of Ellagic Acid (EA) and Hydrogen Peroxide $\left(\mathrm{H}_{2} \mathrm{O}_{2}\right)$ to S. cerevisiae cultures}

Ellagic acid (A15722) from Alfa Aesar (Germany) and $\mathrm{H}_{2} \mathrm{O}_{2}$ Merck (USA) were purchased. The prepared media for the growth and propagation of the yeasts were equally divided into $50 \mathrm{ml}$ in 5 flasks. After waiting at $121^{\circ} \mathrm{C}$ in the autoclave for 1 hour, it was removed and cooled. In addition to the burner flame, $800 \mu \mathrm{L}$ of yeast was planted in each flask. After waiting in the oven for 20 minutes, blind measurement was made. Then, $\mathrm{H}_{2} \mathrm{O}_{2}$ and EA extract were added to the other flasks removed from the oven besides the burner flame. For the preparation of $10 \%$ extract; $10 \mathrm{~g}$ EA was dissolved in $100 \mathrm{~mL}$ distilled water. According to the content of the groups, $5 \mathrm{~mL}$ of EA extract and $300 \mu \mathrm{L}$ of $\mathrm{H}_{2} \mathrm{O}_{2}$ were added to $S$. cerevisiae culture and developed at $30^{\circ} \mathrm{C}[16,18]$.

\section{Cell Development Measurements}

Culture samples were developed at $30^{\circ} \mathrm{C}$ for 1 hour, 3 hours, 5 hours and 24 hours (overnight) and measured using a spectrophotometer at $600 \mathrm{~nm}\left(\mathrm{OD}_{600}\right)$ wavelength.

\section{Protein Isolation for SDS-PAGE}

$1 \mathrm{~mL}$ of $S$. cerevisiae sample was taken and centrifuged at $13000 \mathrm{rpm}$ for 5 minutes. The pellet was dissolved in $500 \mu \mathrm{l}$ TEA ( $\mathrm{pH}:$ 7.5). The cells were kept in ice for 5 minutes after being disintegrated twice for 10 seconds at power 2 with a sonicator (Bandelin Sonopuls, Germany). After centrifuging at $13000 \mathrm{rpm}$ for 10 minutes, the supernatant was removed. For SDS-PAGE, an equal amount of sample was mixed with the protein staining solution and made ready to use for electrophoresis [18].

\section{Sodium Dodecyl Sulfate-Polyacrylamide Gel Electrophoresis (SDS-PAGE) Analysis}

Protein samples of $S$. cerevisiae were added to the wells and boiled for 5 minutes by adding equal amounts of SDS-PAGE sample solution. For electrophoresis, $1 \times$ tank buffer used and $20 \mathrm{~mA}$ current applied 
until the blue band of the dye (bromophenol blue), which enables the movement of proteins in the gel, reaches the end of the gel. The gel stained with Coomassie blue for 30 min-1 hour at room temperature after electrophoresis. Then, the protein bands in the gel washed with paint-removing solution until they become visible. Protein bands between groups examined by taking gel images.

The weights of standard proteins used in the study are as follows; $11 \mathrm{kDa}, 17 \mathrm{kDa}, 20 \mathrm{kDa}, 25 \mathrm{kDa}, 35$ kDa, 48 kDa, 63 kDa, 75 kDa, 180 kDa [16,17].

\section{Total Protein Density Measurements}

Total protein density was determined by spectrophotometer at $595 \mathrm{~nm}\left(\mathrm{OD}_{595}\right)$ according to the bradford method. Protein standards were obtained at different concentrations using Bowine Serum Albumin (BSA) protein. Accordingly, the total amount of protein in the S. cerevisiae groups were calculated $[13,14]$.

\section{Saccharomyces cerevisiae Malondialdehyde (MDA) Analysis}

$200 \mu \mathrm{L}$ sample was taken from the groups. \%20 of $1.5 \mathrm{~mL}$ of acetic acid $(\mathrm{pH}: 3.5)$ and $0.8 \%(\mathrm{pH}: 3.5)$ of thiobarbituric acid (TBA) and $200 \mu \mathrm{L}$ of $8.1 \%$ SDS were added. After adding distilled water to the final volume of $4 \mathrm{ml}$, it was kept in a boiling water bath at $95^{\circ} \mathrm{C}$ for 1 hour. Then, $1 \mathrm{~mL}$ distilled water in a 15: $1(\mathrm{v} / \mathrm{v})$ rate was added from a $5 \mathrm{~mL}$ mixture of $n$-butanol-pyridine and vortexed. After centrifuging at $4000 \mathrm{rpm}$ for $15 \mathrm{~min}$. the upper organic layer was taken and measured spectrophotometrically at $532 \mathrm{~nm}$ wavelength. The results were recorded in $\mathrm{nmol} / \mathrm{mL}[16,17,19]$.

\section{Glutathione (GSH) Levels Measurement}

For the determination of the total amount of GSH, test tubes were prepared according to the working scheme. 0.3 M $2 \mathrm{~mL} \mathrm{Na}_{2} \mathrm{HPO}_{4}$ and $0.4 \% 250 \mu \mathrm{L}$ DTNB were added to $250 \mu \mathrm{L}$ tissue homogenate. In addition, $250 \mu \mathrm{L}$ of distilled water was added to the blind group and the vortexed. The intensity of the color formed in the samples kept at room temperature for 5 minutes and was read at the spectrophotometer at $410 \mathrm{~nm}$ [20].

\section{Statistical Analysis}

All data were evaluated with variance analysis in SPSS 22 packet program. One Way Anova Post Hoc LSD tests were used to determine the differences between the groups. For the reliability of the statistics, measurements were made with at least 3 repetitions. 


\section{RESULTS}

A
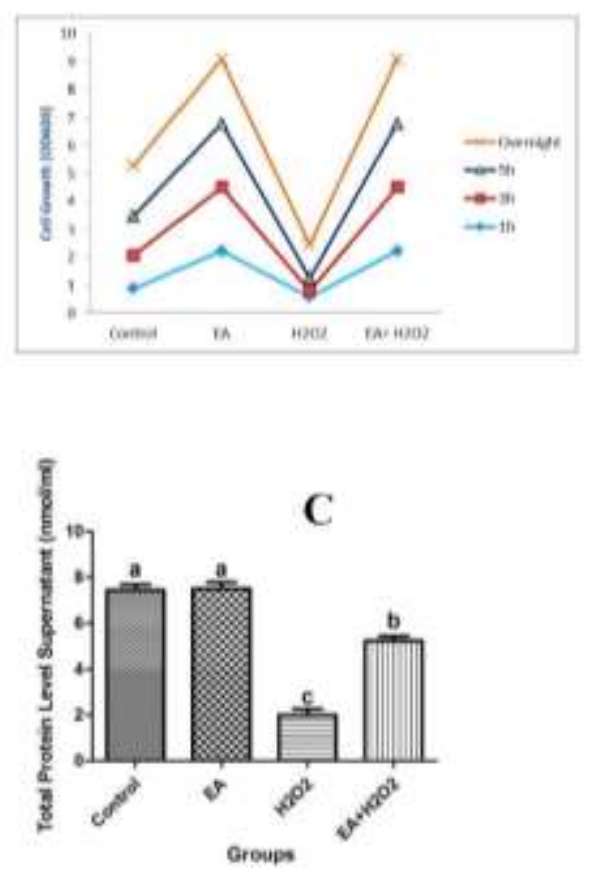

E

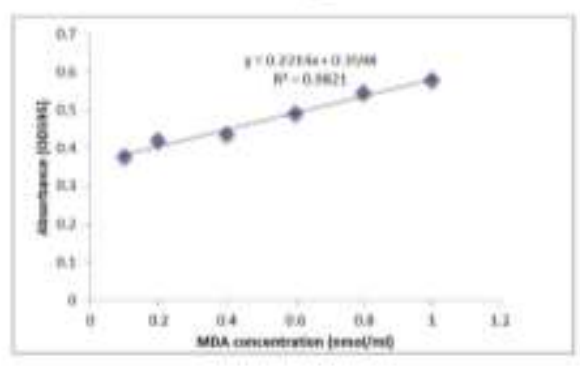

G

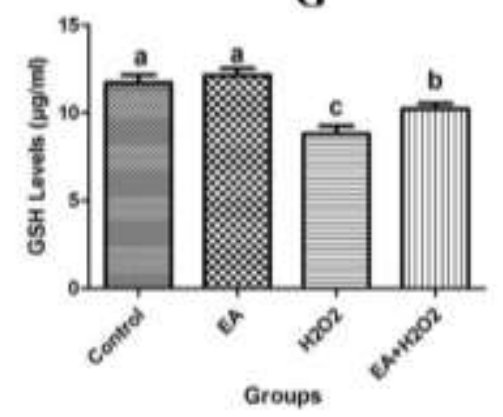

B

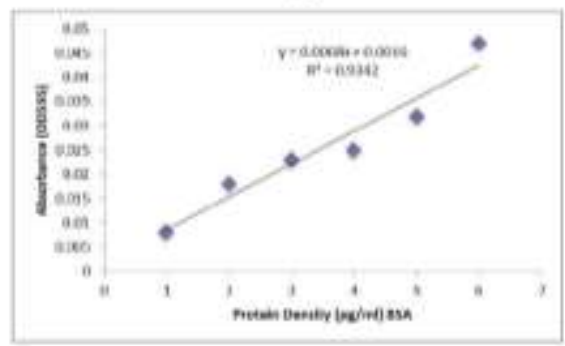

D

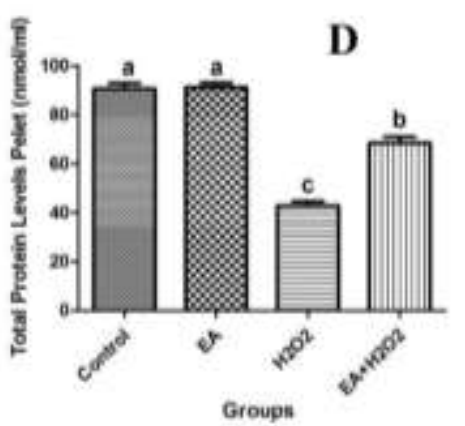

$\mathbf{F}$

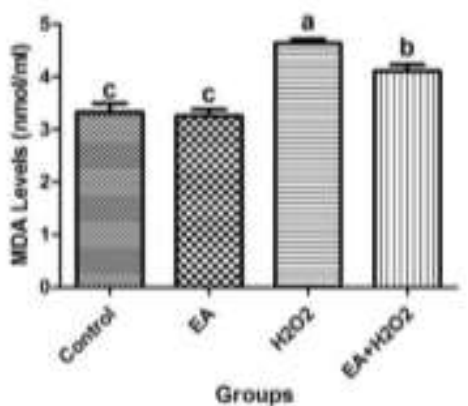

Figure 1. A: Cell growth, B: Standard protein of bradford bovine serum albumin (BSA), C: Supernatant total protein density, D: Pellet total protein density, E: MDA standard, F: MDA levels, G: GSH levels.

When the results of Table 1 and Figure $1 \mathrm{~A}$ are examined, it is seen that there are statistically significant $(p<0.05)$ differences between the groups. It appears that EA increased cell growth. 
Table 1. Saccharomyces cerevisiae cell growth in ellagic acid.

\begin{tabular}{lllll}
\hline Groups & $1 \mathrm{~h}$ & $\mathbf{3 h}$ & $\mathbf{5 h}$ & Overnight \\
\hline Control & $0.88 \pm 0.02^{\mathrm{c}}$ & $1.18 \pm 0.02^{\mathrm{c}}$ & $1.40 \pm 0.02^{\mathrm{c}}$ & $1.80 \pm 0.02^{\mathrm{c}}$ \\
$\mathrm{EA}$ & $2.20 \pm 0.02^{\mathrm{a}}$ & $2.30 \pm 0.02^{\mathrm{a}}$ & $2.28 \pm 0.03^{\mathrm{a}}$ & $2.29 \pm 0.02^{\mathrm{a}}$ \\
$\mathrm{H}_{2} \mathrm{O}_{2}$ & $2.23 \pm 0.02^{\mathrm{d}}$ & $0.20 \pm 0.02^{\mathrm{d}}$ & $0.44 \pm 0.02^{\mathrm{d}}$ & $1.20 \pm 0.02^{\mathrm{d}}$ \\
$\mathrm{EA}+\mathrm{H}_{2} \mathrm{O}_{2}$ & $1.48 \pm 0.02^{\mathrm{b}}$ & $2.27 \pm 0.03^{\mathrm{b}}$ & $2.31 \pm 0.03^{\mathrm{b}}$ & $2.28 \pm 0.03^{\mathrm{b}}$
\end{tabular}

${ }^{\star \star a} a, b, c, d$, among the groups which bearing of different letter are significant $(p<0.05)$. One way Anova Post Hoc LSD test.

When the bradford protein results given in Table 2,3 and Figure 1B,C,D are examined, we can say that EA increases protein synthesis in yeasts. The protein concentration was observed higher in the EA added yeast groups compared to the control group.

Table 2. Bradford supernatant protein density

\begin{tabular}{lc}
\hline Groups (Supernatant) & Total Protein Density $(\mu \mathrm{g} / \mathrm{mL})$ \\
\hline Control & $7.41 \pm 0.02^{\mathrm{a}}$ \\
EA & $7.52 \quad \pm 0.03^{\mathrm{a}}$ \\
$\mathrm{H}_{2} \mathrm{O}_{2}$ & $2.08 \pm 0.02^{\mathrm{c}}$ \\
EA $+\mathrm{H}_{2} \mathrm{O}_{2}$ & $5.20 \pm 0.02^{\mathrm{b}}$
\end{tabular}

a-c: Among the groups which bearing of different letter are significant $(\mathrm{p}<0.05)$. One way Anova Post Hoc LSD test.

Table 3. Bradford pellet protein density

\begin{tabular}{lc}
\hline Groups (Pellet) & Total Protein Density $(\mu \mathrm{g} / \mathrm{mL})$ \\
\hline Control & $89.02 \pm 0.02^{\mathrm{a}}$ \\
EA & $90.05 \pm 0.03^{\mathrm{a}}$ \\
$\mathrm{H}_{2} \mathrm{O}_{2}$ & $42.70 \pm 0.02^{\mathrm{c}}$ \\
EA $+\mathrm{H}_{2} \mathrm{O}_{2}$ & $69.05 \pm 0.03^{\mathrm{b}}$
\end{tabular}

a-c: Among the groups which bearing of different letter are significant $(p<0.05)$. One way Anova Post Hoc LSD test.

When the SDS-PAGE pellet protein bands in Figure 2 were examined, it was observed that EA has a positive effect on protein expression in $S$. cerevisiae. 


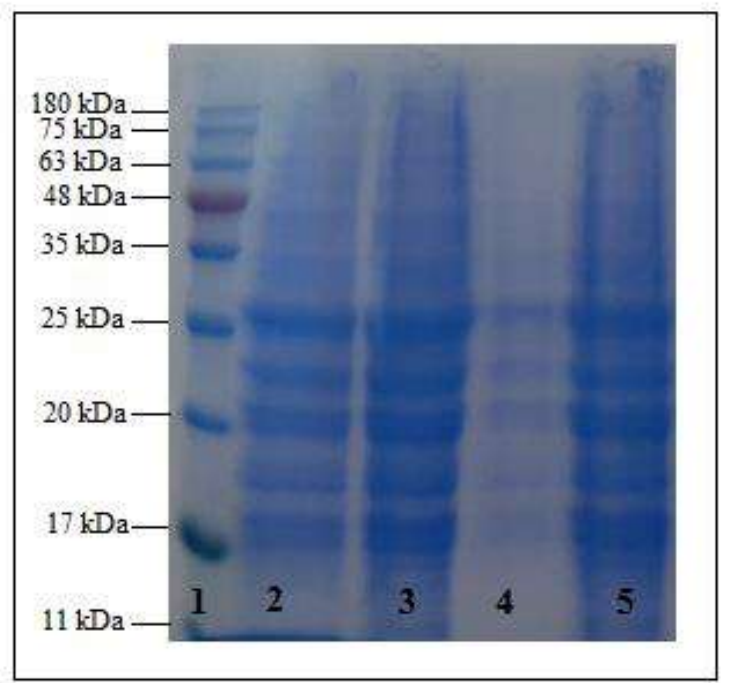

Figure 2. SDS-PAGE pellet total protein band profiles for development at $30^{\circ} \mathrm{C}$. Lanes 1: Marker 2: Control 3: EA 4: $\mathrm{H}_{2} \mathrm{O}_{2} ; 5: \mathrm{EA}+\mathrm{H}_{2} \mathrm{O}_{2}$.

When the MDA levels given in Table 4, Figure 1E, $F$ were examined, there was no statistically significant difference between the control and EA (10\%) groups. The highest MDA level was measured in the $\mathrm{H}_{2} \mathrm{O}_{2}$ group. MDA level was lower in EA $(10 \%)+\mathrm{H}_{2} \mathrm{O}_{2}(15 \mathrm{mM})$ group than $\mathrm{H}_{2} \mathrm{O}_{2}$. These results suggest that $\mathrm{EA}$ is an effective antioxidant in MDA levels due to lipid peroxidation in $S$. cerevisiae.

Table 4. MDA Levels

\begin{tabular}{lc}
\hline Groups & MDA Levels $(\mathbf{n m o l} / \mathbf{m L})$ \\
\hline Control & $3.42 \pm 0.02^{\mathrm{c}}$ \\
EA & $3.30 \pm 0.02^{\mathrm{c}}$ \\
$\mathrm{H}_{2} \mathrm{O}_{2}$ & $4.60 \pm 0.03^{\mathrm{a}}$ \\
$\mathrm{EA}+\mathrm{H}_{2} \mathrm{O}_{2}$ & $4.00 \pm 0.02^{\mathrm{b}}$
\end{tabular}

a-c: Among the groups which bearing of different letter are significant $(p<0.05)$. One way Anova Post Hoc LSD test.

When we examine the GSH levels in our results (Table 5 and Figure 1G), GSH level was the lowest in $\mathrm{H}_{2} \mathrm{O}_{2}$ group and significantly increased in $\mathrm{EA}(10 \%)+\mathrm{H}_{2} \mathrm{O}_{2}(15 \mathrm{mM})$ group.

Table 5. GSH Levels

\begin{tabular}{lc}
\hline Groups & GSH Levels \\
\hline Control & $11.59 \pm 0.02^{\mathrm{a}}$ \\
EA & $12.06 \pm 0.02^{\mathrm{a}}$ \\
$\mathrm{H}_{2} \mathrm{O}_{2}$ & $8.95 \pm 0.04^{\mathrm{c}}$ \\
$\mathrm{EA}+\mathrm{H}_{2} \mathrm{O}_{2}$ & $10.02 \pm 0.02^{\mathrm{b}}$
\end{tabular}

a-c: Among the groups which bearing of different letter are significant $(\mathrm{p}<0.05)$. One way Anova Post Hoc LSD test.

\section{DISCUSSION}

This work and our previous works have some similar results. In our before studies, It has been determined that grape seed extract (GSE) increases cell growth and it has inhibitive effect against to $\mathrm{H}_{2} \mathrm{O}_{2}$ GSE promotes protein synthesis in S. cerevisiae [16]. Also, it was determined that tomato extract (TE) increases the cell development against chromium damage in $S$. cerevisiae and when total protein results examined, TE increases protein synthesis in $S$. cerevisiae [17]. In our other study, it was found that the harmful effects of the $\mathrm{H}_{2} \mathrm{O}_{2}$ radical were eliminated with pomegranate juice and it induced synthesis of $S$. 
cerevisiae cell proteins. However, it has been reported pomegranate juice have a protective role in reducing oxidative damage in S. cerevisiae [21]. In our another study it has been determined that EA has a protective role in the treatment of lung injury and this may have the potential to be used as a future drug for the prevention of lung diseases [22]. Padma and coauthors [23], indicated that EA increases GSH activity in kidney tissue and significantly reduces MDA level. Yang and coauthors [24], stated that there was a significant increase in MDA levels and a decrease in GSH levels in the $\mathrm{H}_{2} \mathrm{O}_{2}$ treated group with in vascular smooth muscle cells compared to the control group. In our study, when the MDA level was evaluated on the basis of groups, there was no statistically significant difference between control and EA groups. However, the $\mathrm{H}_{2} \mathrm{O}_{2}$ and $\mathrm{EA}(10 \%)+\mathrm{H}_{2} \mathrm{O}_{2}(15 \mathrm{mM})$ groups were statistically different $(p<0.05)$ compared to the control group, and the highest MDA level was found in the $\mathrm{H}_{2} \mathrm{O}_{2}(15 \mathrm{mM})$ group.

Salem and coauthors [25], reported that EA has a protective role against oxidative damage in rat liver. Aslan and coauthors [26], remarked that kiwi extract has a protective role to reduce oxidative damage and increase cell growth and protein synthesis in $S$. cerevisiae cell cultures. It was reported that EA and gallic acid isolated from $P$. granatum have antiinflammatory effects [27]. Lin and Yin [28], stated that EA has protective effects against inflammatory and apoptotic stress. They found that intake of EA reduced reactive oxygen species (ROS) and MDA levels, depending on the dose. Rubila and coauthors [29], investigated the protective effects of ginger against lymph tumor and they stated that ginger has a strong antitumor effect. They also found out that ginger levels decreased MDA levels and increased GSH levels. According to the similar results in our study, GSH levels were found high in $\mathrm{EA}(10 \%)+\mathrm{H}_{2} \mathrm{O}_{2}(15 \mathrm{mM})$ group compared to the $\mathrm{H}_{2} \mathrm{O}_{2}(15 \mathrm{mM})$ group with EA application. Aslan [30], indicated that the juice groups taken at different growth times (1, 3, 5 and 72 hours) of banana, strawberry, apple, cherry, watermelon and peach increase cell growth and reduce oxidative stress. Fatima and coauthors [11], examined the antidiabetic effect of EA and it was concluded that it effective in preventing diabetes by providing antioxidant defense in pancreatic cells. Du and coauthors [31], reported that $C$. tinctoria is an antioxidant and antiinflammatory plant used in the treatment of pancreatic disorders in rats. Shirpoor and coauthors [32], investigated the protective effect of ginger extract on ethanol-induced damage in rats. They indicated that ginger, which has antioxidant and antiinflammatory properties, can reduce oxidative DNA damage and oxidative stress caused by ethanol. Wang and coauthors [33], revealed that kiwi fruit has antioxidant properties and is protective for human health. Aslan [34], stated that mulberry extract important protection against $\mathrm{H}_{2} \mathrm{O}_{2}$ damage and it increases the growth of $S$. cerevisiae cells. Gok [35], indicated that EA reduces the rate of liver damage in wistar albino rats. Girish and Pradhan [36], reported that after treatment with EA picrolib and curcumin liver MDA levels in mice were reduced and antioxidant status improved. Zhao and coauthors [37], showed the protective effect of EGCG (epigallocatechin gallate) against $\mathrm{y}$-radiation-induced mortality and cell death of normal cells.

Aslan and coauthors [38], researched the protective role of EA in rats that caused liver damage with carbon tetrachloride $\left(\mathrm{CCl}_{4}\right)$ and they concluded that EA decreased MDA levels. They remarked that EA consumption has an important role in relieving intestinal inflammation and related side diseases [39]. Khan and coauthors [40], studied the effect of pine needles and vitamin E powder on blood biochemistry of female Japanese quail. They stated that adding pine needles and vitamin $E$ to female Japanese quail feed increases improved female quail performance and serum antioxidant system. Aslan et al. [41], investigated the protective role of EA against muscle damage in $\mathrm{CCl}_{4}$-induced rats. Compared to $\mathrm{CCl}_{4}$ group, they revealed that in EA given groups, GSH level increased while MDA levels decreased. Zhao and coauthors [42], found that green tea polyphenols (GTPs), especially its main active ingredient, EGCG, have significant neuroprotective and neuropervative effects against a variety of brain injuries, including some neurodegenerative diseases. In present study, it was observed that total pellet protein density and supernatant total protein density increased significantly in $\mathrm{EA}(10 \%)+\mathrm{H}_{2} \mathrm{O}_{2}(15 \mathrm{mM})$ group compared to the $\mathrm{H}_{2} \mathrm{O}_{2}(15 \mathrm{mM})$ group. Popovic and coauthors [43], found out that Cranberry (Cornus mas L.) fruit inhibits lipid peroxidation and oxidative stress. Aslan and coauthors [44], indicated that according to the control group, in the pomegranate juice (PJ) groups, fatty acid synthesis, vitamin content and cell density increased and it was stated that more banding was observed in $\mathrm{PJ}$ groups compared to the control. As a result, this investigations showed us that EA extract provides a strong protection against damage in $S$. cerevisiae thanks to its antioxidant properties. 


\section{CONCLUSION}

The present study reveals the inhibitory effect of EA against cell death in $S$. cerevisiae. The results of the present study illustrate that EA significantly reduces oxidative damage and thus has a positive effect on yeast growth (Figure 3). It also may have similar effects on humans as its effects on S. cerevisiae.

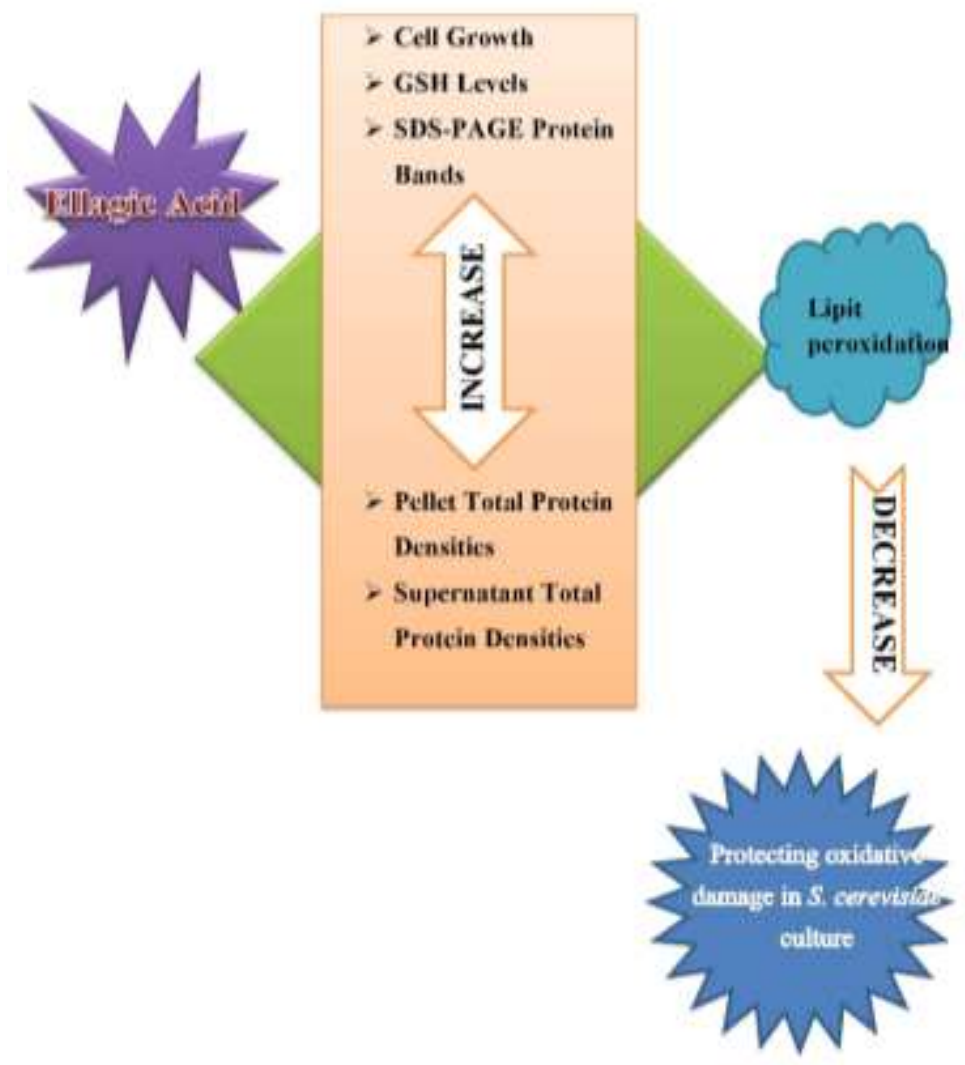

Figure 3. The effect of ellagic acid on S. cerevisiae cell growth, protein synthesis, GSH and MDA levels.

Funding: This article have been presented as orally at participation in the $9^{\text {th }}$ National Molecular Biology and Biotechnology Congress 18-20 December 2020.

Conflict of interest disclosure: All authors declare that there are no conflicts of interest for this study.

Author contributions: AA: Planning and writing of this article, analysing of some molecular parameters, applications on S. cerevisiae and evaluating of results, OG: applications and laboratory analysis, SB: applications and laboratory analysis.

\section{REFERENCES}

1. Ranawat L, Bhatt J, Patel J. Hepatoprotective activity of ethanolic extracts of bark of Zanthoxylum armatum DC in $\mathrm{CCl}_{4}$ induced hepatic damage in rats. J Ethnopharmacol. 2010; 127:777-80.

2. Garcia-Nino WR, Zazueta C. Ellagic acid: Pharmacological activities and molecular mechanisms involved in liver protection. Pharmacol Res. 2015; 97:84-103.

3. Arora B, Choudhary M, Arya P, Kumar S, Choudhary N, Singh S. Hepatoprotective potential of Saraca ashoka (Roxb.) de wilde bark by carbon tetrachloride induced liver damage in rats. Bull. Fac. Pharm. Cairo Univ. 2015;53: 23-8.

4. Firdaus F, Zafeer MF, Anis E Ahmed M, Afza M. Ellagic acid attenuates arsenic induced neuro-inflammation and mitochondrial dysfunction associated apoptosis. Toxicol Rep. 2018; 5: 411-7.

5. Pavlova EL, Simeonova LS, Gegova GA. Combined efficacy of oseltamivir, isoprinosine and ellagic acid in influenza A(H3N2)-infected mice. Biomed Pharmacother. 2018; 98: 29-35.

6. Hussein $\mathrm{RH}$, Khalifa $\mathrm{FK}$. The protective role of ellagitannins flavonoids pretreatment against $\mathrm{N}$ nitrosodiethylamine induced-hepatocellular carcinoma. Saudi J Biol Sci. 2014; 21: 589-96.

7. Arab HH, Gad AM, Fikry EM, Eid AH. Ellagic acid attenuates testicular disruption in rheumatoid arthritis via targeting inflammatory signals, oxidative perturbations and apoptosis. Life Sci. 2019; 239: 117012. 
8. Zheng D, Lv C, Sun X, Wang J, Zhao Z. Preparation of a supersaturatable self-microemulsion as drug delivery system for ellagic acid and evaluation of its antioxidant activities. J Drug Deliv Sci Technol. 2019; 53:101209.

9. Mehrzadi S, Bahrami N, Mehrabani M, Motevalian M, Mansouri E, Goudarzi M. Ellagic acid: A promising protective remedy against testicular toxicity induced by arsenic. Biomed Pharmacother. 2018; 103:1464-1472.

10. Mady FM, Shaker MA. Enhanced anticancer activity and oral bioavailability of ellagic acid through encapsulation in Biodegradable Polymeric Nanoparticles. Int J Nanomedicine. 2017; 12: 7405.

11. Fatima N, Hafizur RM, Hameed A, Ahmed S, Nisar M, Kabir N. Ellagic acid in Emblica officinalis exerts anti diabetic activity through the action on $\beta$ cells of pancreas. Eur J Nutr. 2017; 56: 591-601.

12. Ahad A, Ganai AA, Mujeeb M, Siddiqui WA. Ellagic acid, an NF-kB inhibitor, ameliorates renal function in experimental diabetic nephropathy. Chem Biol Interact. 2014; 219: 64-75.

13. Herrero E, Ros J, Bellí G, Cabiscol E. Redox control and oxidative stress in yeast cells. Biochim Biophys Acta Gen Subj. 2008; 1780(11): 1217-35.

14. Odriozola-Serrano I, Puigpinós J, Oliu GO, Herrero E, Martín-Belloso O. Antioxidant activity of thermal or nonthermally treated strawberry and mango juices by Saccharomyces cerevisiae growth based assays. LWT. 2016; 74:55-61.

15. Aslan A, Can Ml. Protein expression product alterations in Saccharomyces cerevisiae. Prog Nutr. 2017; 19(1): 81-5.

16. Aslan A, Gok O, Beyaz S. The protective effect of grape seed extract against to hydrogen peroxide-induced damage in Saccharomyces cerevisiae. Iğdır Univ. J. Inst. Sci. \& Tech. 2019a; 9(4): 2216-24.

17. Aslan A, Beyaz S, Gok O. The protective effect of tomato extract against to chromium-induced damage in Saccharomyces cerevisiae. Erzincan University Journal of Science and Technology. 2019b; 12(2): 1048-55.

18. Beyaz S, Dalkılıç LK, Gök Ö, Aslan A. Effect of Black Mulberry (Morus nigra L.) and Cranberry (Cornus mas L.) on some molecular biological and biochemical parameters against oxidative damage caused by hydrogen peroxide in Saccharomyces cerevisiae. BEU Journal of Science. 2020; 9(3): 1134-44.

19. Ohkawa H, Ohishi N, Yagi K. Assay for Lipid Peroxides in Animal Tissues by Thiobarbituric Acid Reaction. Anal Biochem 9. 1979; 5: 351-8.

20. Cinar K. Investigation of the effect of apricots on the liver tissue glutation s-transferase-pi (GST-P) gen expression, GST, GSH-PX, GSH and MDA levels in rats that are created subcronic acrylamid toxicity [Medical specialty thesis]. Malatya: Inonu university faculty of medicine; 2010. $96 \mathrm{p}$.

21. Aslan A, Can MI, Boydak D. Anti-oxidant effects of pomegranate juice on Saccharomyces cerevisiae cell growth. Afr J Tradit Complement Altern Med. 2014a; 11 (4): 14-8.

22. Aslan A, Hussein YT, Gok O, Beyaz S, Erman O, Baspinar S. Ellagic acid ameliorates lung damage in rats via modulating antioxidant activities, inhibitory effects on inflammatory mediators and apoptosis-inducing activities. Environ Sci Pollut Res Int. 2020a; 27: 7526-37.

23. Padma VV, Selvi PK, Sravani S. Protective effect of ellagic acid against TCDD-induced renal oxidative stress: Modulation of CYP1A1 activity and antioxidant defense mechanisms. Mol Biol Rep. 2014; 41: 4223-32.

24. Yang X, Wang Q, Wang C, Qin, X, Huang Y, Zeng R. Synthesis and protective effect of kaempferol-3'- sulfonate on hydrogen peroxide induced injury in vascular smooth muscle cell. Chem Biol Drug Des. 2016;87(6):841.

25. Salem AM, Mohammaden TF, Ali MAM, Mohamed EA, Hassan HF. Ellagic and ferulic acids alleviate gamma radiation and aluminium chloride-induced oxidative damage. Life Sci. 2016;160:2-11.

26. Aslan A, Gok O, Erman O. The protective effect of kiwi fruit extract against to chromium effect on protein expression in Saccharomyces cerevisiae. Prog Nutr. 2017;19(4):472-6.

27. BenSaad LA, Kim KH, Quah CC, Kim WR, Shahimi M. Anti-inflammatory potential of ellagic acid, gallic acid and punicalagin A\&B isolated from Punica granatum. BMC Complement Altern Med. 2017; 17(1): 47.

28. Lin MC, Yin MC. Preventive effects of ellagic acid against doxorubicin-induced cardio-toxicity in mice. Cardiovasc toxicol. 2013;13(3):185-93.

29. Rubila S, Ranganathan TV, Sakthivel KM. "Protective effect of Zingiber officinale against dalton's lymphoma ascites tumour by regulating inflammatory mediator and cytokines". Appl Biochem Biotechnol. 2016;180(8):148296.

30. Aslan A. The effects of different essential fruit juice and their combination on Saccharomyces cerevisiae cell growth. Prog Nutr. 2015;17(1):36-40.

31. Du D, Yao L, Zhang R, Shi N, Shen Y, Yang X, et al. Protective effects of flavonoids from Coreopsis tinctoria nutt. on experimental acute pancreatitis via Nrf-2/ARE-mediated antioxidant pathways. J Ethnopharmacol. 2018;224:261-72.

32. Shirpoor A, Rezaei F, Fard AA, Afshari AT, Gharalari FH, Rasmi Y."Ginger extract protects rat's kidneys against oxidative damage after chronic ethanol administration". Biomed Pharmacother. 2016; 84: 698-704. 
33. Wang Y, Shan T, Yuan Y, Zhang Z, Guo C, Yue T. Evaluation of penicillium expansum for growth, patulin accumulation, nonvolatile compounds and volatile profile in kiwi juices of different cultivars. Food Chem. 2017; 228: 211-8.

34. Aslan A. Cell culture developing and the imaging of total protein product changing with SDS-PAGE in Saccharomyces cerevisiae. Prog Nutr. 2018; 20 (1): 128-32.

35. Gok O. The Effect of Ellagic Acid on Some Apoptotic Proteins Expression in Liver of Rats Experimentally to Made up Damage with Carbon Tetrachloride [Master Thesis]. Elazığ: Firat University Institute of Science and Technology; 2017.74 p.

36. Girish C, Pradhan SC. Hepatoprotective activities of picroliv, curcumin, and ellagic acid compared to silymarin on carbon-tetrachloride-induced liver toxicity in mice. J Pharmacol Pharmacother. 2012; 3(2): 149-55.

37. Zhao H, Zhu W, Xie P, Li H, Zhang X, Sun X, et al. Prospectie phase II trial of EGCG in treatment of acute radiation-induced esophagitis for stage III lung cancer. Radiother Oncol. 2015; 114: 351-6.

38. Aslan A, Gok O, Erman O, Kuloglu T. Ellagic acid impedes carbontetrachloride-induced liver damage in rats through suppression of NF-kB, Bcl-2 and regulating Nrf-2 and caspase pathway. Biomed Pharmacother. 2018; 105: 662-9.

39. Iglesias DE, Cremonini E, Fraga CG, Oteiza PI. Ellagic acid protects Caco-2 cell monolayers against inflammation-induced permeabilization. Free Radic Biol Med. 2020; 152: 776-86.

40. Khan IU, Shah AA, Sahibzada FA, Hayyat A, Nazar M, Mobashar M, et al. Carcass characteristics and serum biochemical profile of Japanese quail by the supplementation of pine needles and vitamin $\mathrm{E}$ powder. Biologia. 2019;74(8):993-1000.

41. Aslan A, Beyaz S, Gok O, Erman O. The effect of ellagic acid on caspase-3/bcl-2/Nrf-2/NF-kB/TNF-a/COX-2 gene expression product apoptosis pathway: a new approach for muscle damage therapy. Mol Biol Rep. 2020b; 47:2573-82.

42. Zhao X, Liu F, Jin H, Li R, Wang Y, Zhang W. Involvement of Pkca and erk1/2 signaling pathways in EGCG's protection against stress-induced neural injuries in wistar rats. Neuroscience. 2017; 346: 226-37.

43. Popovic BM, Stajner D, Slavko K, Sandra B. Antioxidant capacity of cornelian cherry (Cornus mas L.)-comparison between permanganate reducing antioxidant capacity and other antioxidant methods. Food Chem. 2012; 134 (2): 734-41.

44. Aslan A, Baspinar S, YIlmaz O. Is pomegranate juice has a vital role for protective effect on Saccharomyces cerevisiae growth?. Prog Nutr. 2014b;16(3):212-7.

2021 by the authors. Submitted for possible open access publication under the terms and conditions of the Creative Commons Attribution (CC BY NC) license (https://creativecommons.org/licenses/by-nc/4.0/). 